\title{
Postsecondary Mathematics during the Covid-19 Pandemic: A Systematic Review
}

By Dr. Manuel Rodriguez

West Coast University

Abstract- The Coronavirus 2019 pandemic has brought about the need for prompt and dynamic changes in the educational system, including the use of e-Learning. Mathematics is a particularly abstract field of study that may be difficult to teach through e-Learning. Psychosocial factors pandemic may further challenge educators and students in mathematics e-Learning during the pandemic. This systematic review aims to explore the transitional experiences of postsecondary educators and students in mathematics e-Learning during the Coronavirus 2019 pandemic. Nine articles met the criteria and were included for synthesis. Findings revealed that the most utilized and preferred technologies were Google Classroom, Moodle, and WhatsApp. Changes in educators' practices included increased hours spent on teaching preparation and tasks, reduced use of gestures, sending notes prior to lessons, and reduced student interactions. Advantages of mathematics e-Learning perceived by educators included improvements in student involvement, lesson planning, teaching style, and comfort in technologies. Major challenges perceived by educators were reduced student interactions, lack of special software for mathematics, difficulty monitoring student progress, and difficulty with testing.

Keywords: covid-19, e-learning, higher education, mathematics, systematic review.

GJHSS-G Classification: FOR Code: 130399

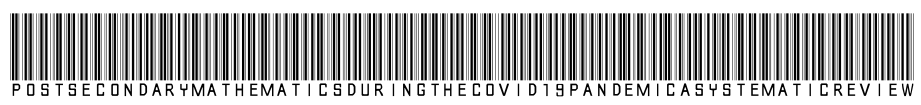

Strictly as per the compliance and regulations of:

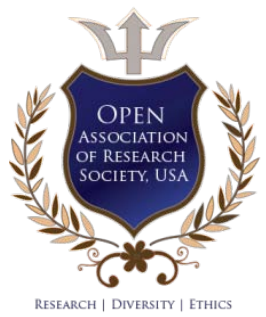

(C) 2021. Dr. Manuel Rodriguez. This research/review article is distributed under the terms of the Attribution-NonCommercialNoDerivatives 4.0 International (CC BY-NC-ND 4.0). You must give appropriate credit to authors and reference this article if parts of the article are reproduced in any manner. Applicable licensing terms are at https://creative commons.org/licenses/by-nc$\mathrm{nd} / 4.0 \%$ 


\title{
Postsecondary Mathematics during the Covid-19 Pandemic: A Systematic Review
}

\author{
Dr. Manuel Rodriguez
}

Abstract- The Coronavirus 2019 pandemic has brought about the need for prompt and dynamic changes in the educational system, including the use of e-Learning. Mathematics is a particularlyabstract field of study that may be difficult to teach through e-Learning. Psychosocial factors pandemic may further challenge educators and students in mathematics eLearning during the pandemic. This systematic review aims to explore the transitional experiences of postsecondary educators and students in mathematics e-Learning during the Coronavirus 2019 pandemic. Nine articles met the criteria and were included for synthesis. Findings revealed that the most utilized and preferred technologies were Google Classroom, Moodle, and WhatsApp. Changes in educators' practices included increased hours spent on teaching preparation and tasks, reduced use of gestures, sending notes prior to lessons, and reduced student interactions. Advantages of mathematics e-Learning perceived by educators included improvements in student involvement, lesson planning, teaching style, and comfort in technologies. Major challenges perceived by educators were reduced student interactions, lack of special software for mathematics, difficulty monitoring student progress, and difficulty with testing. Students' perceived advantages of mathematics e-Learning included improvements in technological skills, problem solving, and communication and research skills. Major challenges perceived by students were connectivity issues, data and device affordability, being unprepared for e-Learning, increased anxiety for mathematics e-Learning, lack of practical works or simulations, unclear instructions, insufficient feedback, and distractions and responsibilities at home. Based on these findings, mathematics e- Learning may be necessary and may have benefits but still involves several challenges for both postsecondary educators and students.

Keywords: covid-19, e-learning, higher education, mathematics, systematic review.

\section{INTRODUCTION}

1 he Coronavirus 2019 (Covid-19) pandemic, which began in December of 2019 in Wuhan, China, has had a significant impact on various fields across the globe, including the field of higher education (Marinoni et al., 2020). Based on the United Nations Educational, Scientific and Cultural Organization (UNESCO) reports, 185 nations declared closure of their educational institutions beginning April of 2020, thereby impeding on the education of around 1,542,412,000 learners (89.4\% of overall enrolled learners) around the world (Marinoni et al., 2020). Such a large scale and dynamic change has never occurred before, and

Author: Ph.D, West Coast University, Doral, Florida Miami, FL 33175 , United States.e-mail: manrodriguez@westcoastuniversity.edu warranted extensive adjustments to educational systems (Cassibba et al., 2021). Since then, several learners and educators have experienced unforeseen radical reconstructions of education as they worked or studied from home (Neuwirth et al., 2020). Both learners and educators have had to adjust to the new system of eLearning.

E-Learning has been defined as the use of various types of information and communications technologies (ICT), such as e-mail, software, and learning management systems(LMS), among others, for the purposes of education (Ayu, 2020). E-Learning is a part of the fourth industrial revolution (4IR), which involves the technological integration of the physical, biological, and digital aspects of life (Sakhapov \& Absalyamova, 2018). Although the 4IR beganearlier than the Covid-19 pandemic, disparities in terms of readiness still exists between nations and between individuals (Naidoo, 2020; Sakhapov \& Absalyamova, 2018). Furthermore, although individuals may be accustomed to using technologies for personal uses, e-Learning is substantially different (Nsengimana et al., 2021). The terms digital natives and digital immigrants illustrate the disparities in readiness (Naidoo, 2020). Digital natives are individuals who are well-versed in the use of latest technologies, while digital immigrants comprise those who are unfamiliar with technology and may tend to rely primarily on printed materials prior to using digital technology (Naidoo, 2020). With the sudden adjustments made due to Covid-19, digital immigrants may have difficulties transitioning to the digital lifestyle.

Other psychosocial factors may also be at play during the Covid-19 pandemic. Given the new virtual classroom environment and possible distractions in the physical environment, the learners may have difficulties focusing on their lessons or participating in discussions (Neuwirth et al., 2020). At the same time, educators may have trouble adjusting to teaching on a screen with minimal visual feedback from and engagement from their students (Neuwirth et al., 2020). In addition to these obstacles, Ludwig (2021) proposed the phenomenon of Covid despair, which describes negative psychological state of individuals during the pandemic. During this difficult time, individuals may struggle with financial stress, unemployment, cramped living spaces, lack of recreation, social isolation, and immediate deportation of international students. Given these difficulties, the present generation of young adults (Gen Z) were found 
to be the loneliest and most negatively affected generation in terms of mental health (Ludwig, 2021). Such psychosocial factors may serve as additional burdens that can impact the transitional experiences of both learners and educators to e-Learning during the Covid-19 pandemic.

Mathematics is a subject of particular interest for the topic of e-Learning. Cassibba et al. (2021) purported that mathematics was a highly abstract field of study that involved a great deal of cognitive metaphors so that learners could objectify and understand mathematical topics with what they already know. As such, the use of gestures and body language was purported to be useful in helping learners to visualize the mathematical objects (Cassibba et al., 2021).

Mathematics is also known for its use of specific language and symbols, which should be supported in e-Learning platforms (Ahn \& Edwin, 2018). Additionally, mathematics may best be taught synchronously to allow for practice (Nsengimana et al., 2021). Collaboration was also cited as a valuable factor for mathematics education to allow learners to work together on solutions for mathematical problems (Naidoo, 2020). The aspects of practice and collaboration, however, may be more restricted in eLearning (Naidoo, 2020; Nsengimana et al., 2021).

Although various software have been developed specifically for mathematics e-Learning, use of such software in practice remains scarce because of the difficulties in setting them up and usingthem, in addition to the high costs associated with them (Ahn \& Edwin, 2018). Mathematics education may thus need considerable adjustment from traditional face-to-face learning to e- Learning. A synthesis of the evidence on the current state of postsecondary mathematics eLearning may be valuable to determine possible gaps and challenges that could be addressed or improved upon for better transitional experiences of educators and students.

To address the issues presented regarding mathematics education in e-Learning during the Covid19 pandemic, this systematic review involved the consolidation of the available data on educators' and learners' experiences. The main research question for this review is: What are the transitional experiences of postsecondary educators and students in mathematics e-Learning during the Covid-19 pandemic? This is divided further into four sub-research questions:

$R Q 1$ : Which technologies were frequently utilized for postsecondary mathematics e- Learning during the Covid-19 pandemic?

$R Q 2:$ What were the changes in educators' practices of teaching postsecondary mathematics during the Covid19 pandemic?
RQ3: How did postsecondary educators perceive mathematics e-Learning during theCovid-19 pandemic?

RQ4: How did postsecondary students perceive mathematics e-Learning during theCovid-19 pandemic?

\section{MeTHOD}

Systematic reviews are used to collate evidence regarding specific questions with a search strategy that is explicit, systematic, and replicable (Gough et al., 2017). The use of clearlydefined inclusion and exclusion criteria is vital for the search strategy. The resulting studies from the search are coded and synthesized to arrive at findings that address the research questions, highlight gaps and inconsistencies on existing evidence, and serve as potential guides for practice (Gough et al., 2017). For this systematic review, nine articles regarding the topic of transitional experiences in postsecondary mathematics e-Learning were mapped.

\section{a) Search Strategy}

The inclusion criteria for this systematic review were peer-reviewed studies that were published in the English language and involved postsecondary mathematics education during the Covid-19 pandemic, with the sample of postsecondary educators, students, or both. As the Covid-19 pandemic began in December of 2019, the search was limited to articles published in 2020 and 2021. Exclusion criteria were articles that had no full text available, not relevant to thetopic, and those in the forms of systematic reviews, meta-analyses, letters to the Editor, commentaries, or theoretical articles. Following the Preferred Reporting Items for Systematic Reviews and Meta-Analyses (PRISMA) 2020 statement (Page et al., 2021), a search was conducted on September 2021 using four databases: ERIC, Google Scholar, JSTOR, and MDPI, resulting in an initial number of 26,497 records identified (see Figure 1). Search terms utilized are also presented in Table 1. 


\section{Identification of studies via databases and registers}

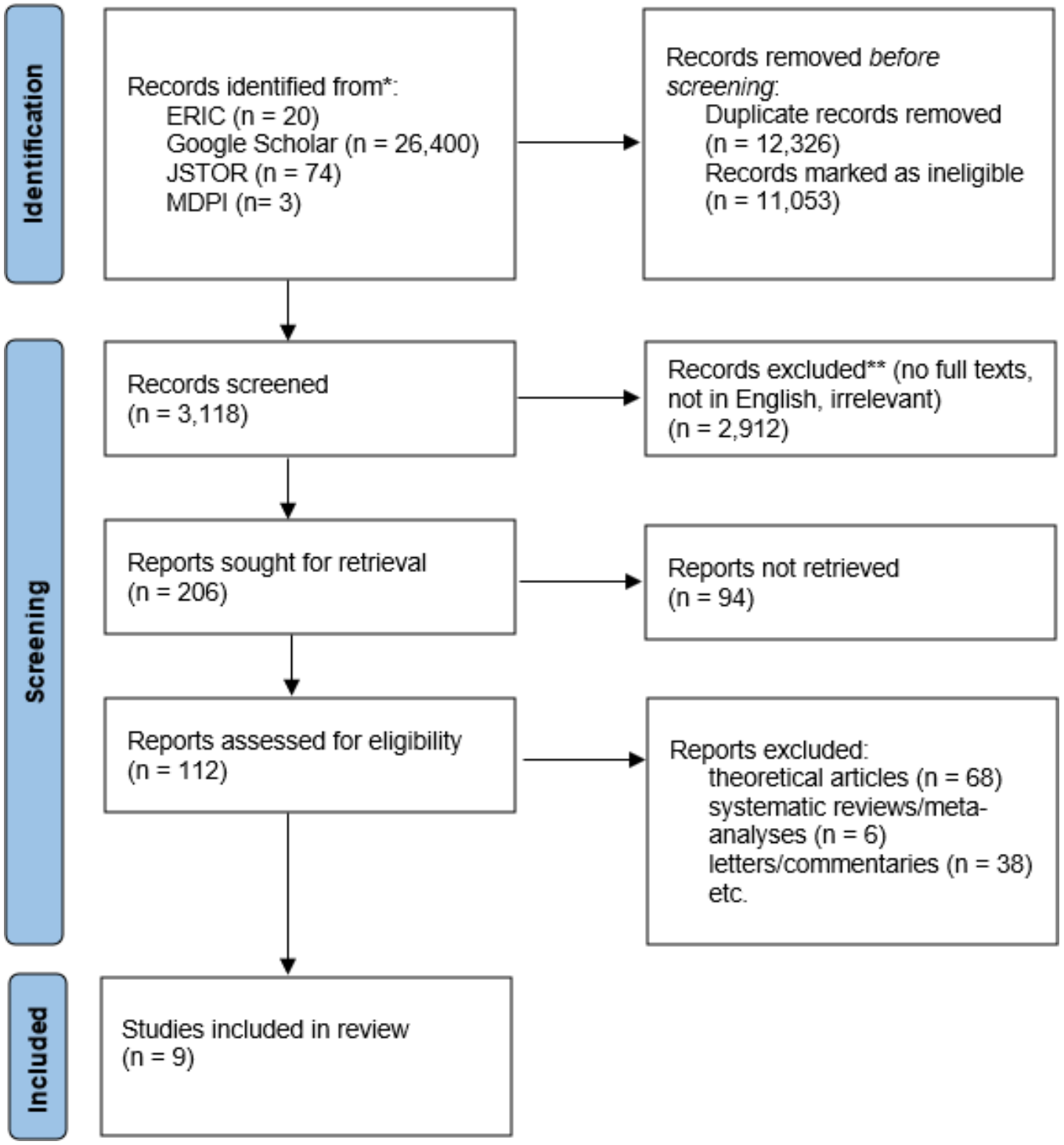

Figure 1: PRISMA diagram (slightly modified after Page et al., 2021)

Table 1: Search Terms Used

\begin{tabular}{ll}
\hline \multicolumn{1}{c}{ Topic } & \multicolumn{1}{c}{ Search terms } \\
\hline Mathematics & "mathematics" OR "math" \\
Higher Education & "higher education" OR "tertiary education" OR "postsecondary education" OR \\
& "college" OR "university" \\
Coronavirus & "Coronavirus" OR "Covid" OR "Covid-19" OR "SARS-CoV 2" \\
e-Learning & "e-Learning" OR "distance learning" OR "distance education" OR "online \\
& learning" OR "online education" OR "virtual learning" OR "virtual education" \\
\hline
\end{tabular}

The titles and abstracts of the initial records were screened. Upon removal of duplicate records, 14,171 records remained. Further removal of ineligible records resulted in 3,118 remaining records. Of these records, 2,912 were removed based on the exclusion criteria, and 94 were unavailable for retrieval. The remaining 112 were thoroughly assessed based on the inclusion criteria, and 103 were removed. This process resulted in a total of nine records included in this systematic review.

b) Coding, Data extraction, and Analysis

To extract the data from the studies, a coding process was developed, which included article information (method, sample, and countries of 
authorship). Study results were also coded based on their relationship with the sub-research questions, which included the technologies used for mathematics eLearning, changes in practices, educators' perceptions, and students' perceptions. The coding, extraction, and analysis processes were conducted with the NVivo software version 12. Because most of the studies were qualitative in nature, meta-analysis could not be conducted. It should be noted that percentages from the analyses may not amount to $100 \%$ due to rounding .

\section{Study Characteristics}

\section{a) Methodological Characteristics}

Among the nine studies included in this review, five studies (55.6\%) used qualitative methods, two studies $(22.2 \%)$ used quantitative methods, and two studies (22.2\%) used mixed methods. Although the majority of the studies were qualitative, only two out of the nine studies (22.2\%) were interpretive in nature, with the rest being descriptive. Almost all studies involved an online survey with the exception of Naidoo (2020), who utilized online workshops and onlinediscussion forums, and Siregar et al. (2021), who utilized observations, interviews, and other files in their study.

Various types of analyses were used in the qualitative studies, including content analysis (Nsengimana et al., 2021), open coding (Naidoo, 2020), and the Miles and Huberman procedure(Sulistyani et al., 2021), while the others did not specify the type of analysis used. Both of the quantitative studies involved descriptive statistics, and did not specify the instrument used for analysis. No correlations or causations were established in the quantitative studies. The mixed methods studies employed more sophisticated processes of analysis including McNemar's tests, Chisquare tests, Kruskal-Wallis tests, and thematic analyses. Significant correlations were established in Lopez et al.'s (2021) study regarding self-reported additional hours spent teaching and increase in technologies during the transition to e-Learning. Cassibba et al. (2021) likewise reported significant increases in technologies used, as well as significant differences in willingness to continue e-Learning based on professors' age.

\section{b) Geographical Characteristics}

The studies included in this systematic review encompassed six nations. Three studies (33.3\%) took place in Indonesia, two (22.2\%) in the United States, and one study (11.1\%) each for Italy, Rwanda, South Africa, and Ghana. Interestingly, the locations for the studies were mostly clustered around the continent of Africa and the nation of Indonesia. Although Africa hasbeen known to be significantly affected in past pandemics, the Ghanaian and Rwandan governments imposed restrictions promptly, allowing for minimal cases in their respective nations (Attiah, 2020). Contrastingly, South
Africa experienced a swift rise in Covid-19 cases early in March 2020 before imposing restrictions (Stiegler \& Bouchard, 2020). As such, the findings of the three African studies are reflective of diverse situations albeit being within the same continent. It should also be noted that internet usage is highly limited in Africa, with only $24 \%$ of the population having access due to increased costs and poor connectivity, which couldbe a factor for e-Learning (Tamrat \& Teferra, 2020).

Indonesia, the nation with the greatest number of studies in this systematic review, was affected by Covid-19 early on as well. Reports from June 2020 indicated that Indonesia had the highest number of active cases in Southeast Asia, but at the same time, the lowest number of infection per capita (Olivia et al., 2020). The rise in the number of cases was attributed to the slow response of the Indonesian government when its neighboring countries were already imposing lockdowns (Olivia et al., 2020). Notably, Indonesia was reportedly unprepared for e- Learning as well, with only nine universities having established systems for eLearning before the pandemic (Siregar et al., 2021). The three Indonesian studies in this review took place in different cities. It should be noted that all Indonesian studies in this systematic review utilized purely qualitative methods, which does not allow for a generalizable view of the nation.

Although two studies took place in the United States, the data was still limited as Ludwig's (2021) sample comprised students from a single university in western United States, while Lopez et al.'s (2021) sample only included educators from four higher education institutions in South and Central Texas. Only one study was found in Europe. The single European study was conducted in Italy, a nation that also saw a steep rise of Covid-19 cases early in March 2020, and adopted strict measures to contain the outbreak (Saglietto et al., 2020). Although the use of technologies in higher education was not new to Italy at the time of the Covid-19 outbreak, several traditional universities that used blackboard and chalk still existed (Cassibba et al., 2021). No studies that met the criteria were found in South America and Australia.

\section{c) Sample Characteristics}

The criteria for the study samples in this systematic review included either educators or students in the postsecondary levels. Five studies (55.6\%) involved educators, two studies (22.2\%) involved undergraduate students, and two studies (22.2\%) involved postgraduate students. Notably, the two studies involving postgraduate students both took place in Africa. Allthree Indonesian studies involved lecturers. Although the North American studies in this reviewtook place in different states of the United States, it is the only continent with a study on educators and on students. 
For the qualitative studies, sample sizes were mostly between 14 to 31 , with the exception of Siregar et al. (2021), whose sample included 200 lecturers; however, it should be noted that these 200 lecturers were from a single university, thus also limiting the generalizability of their results. The two quantitative studies had 120 and 467 undergraduate students for their samples, while the mixed methods studies had 27 and 51 professors for their samples. These could be somewhat proportional to the study populations, as the undergraduate student population generally outnumbers the population of educators and postgraduate students.

\section{Results}

RQ1: Which technologies were frequently utilized for postsecondary mathematics e-Learningduring the Covid19 pandemic?

Seven studies (77.8\%) reported on the technologies frequently used for e-Learning during the Covid-19 pandemic (see Table 2). The studies addressing this sub-research question comprised one (14.3\%) quantitative, two (28.6\%) mixed methods, and four $(57.1 \%)$ qualitative studies. All studies indicated platforms used or preferred by educators or students. Only one study (Agormedah et al., 2020) reported on the devices used, or lack thereof, for e-Learning, as well as self-reported proficiency for such devices. This unique finding highlighted the challengeof access to technology for e-Learning in Ghana (Agormedah et al., 2020).

Qualitative data regarding the challenges associated with technologies used were presented in three studies (33.3\%). Two of these studies indicated lack of training and preparation as major challenges (Lopez et al., 2021; Naidoo, 2020), while specific programs were cited by Irfan et al. (2020) and Naidoo
(2020). Notably, Siregar et al. (2021) were the only ones to report on an additional factor of generational differences in terms of technologies used for e-Learning, noting how millennials born between 1981 to 1994 were more likely to combine group chat and LMS platforms while baby boomers born between 1946 to 1964 were more likelyto use only group chat platforms.

Preferences for and uses of LMS platforms appeared to vary between studies; however, the most frequently cited in this review were Google Classroom (3/7, 42.9\%) and Moodle (3/7, 42.9\%). Based on the studies in this systematic review, Google Classroom appeared to be more popular in Indonesia, while it was only ranked third in Ghana in terms of student awareness (Agormedah et al., 2020; Irfan et al., 2020; Sulistyani et al., 2021). Moodle was ranked second in terms of Ghanaian student awareness (Agormedah et al., 2020); however, South African students in Naidoo's (2020) study reported feeling uncomfortable with Moodle, and indicated that response times were too long with Moodle.

In terms of communication platforms, WhatsApp appeared to be the most popular in general, as it was specifically cited in four out of seven $(57.1 \%)$ of the studies. Notably, WhatsApp was the most preferred or most used communications platform in all of these studies.Only educators (37\%) in Cassibba et al.'s (2021) study in Italy reported using mathematical software for e-Learning, and only one educator (7.1\%) in Sulistyani et al.'s (2021) study in Indonesia reported using an evaluation software out of the seven studies. Although 75\% of Lopez et al.'s (2021) participant educators reported giving online quizzes, they did not specify whether these were conducted using an evaluation software.

Table 2: Technologies Used for e-Learning

\begin{tabular}{|c|c|c|c|c|}
\hline Author (Year) & Method & Sample & Location & Results \\
\hline $\begin{array}{l}\text { Agormedah et } \\
\text { al. (2020) }\end{array}$ & $\begin{array}{c}\text { Quantitative } \\
\text { survey }\end{array}$ & $\begin{array}{c}467 \\
\text { under- graduate } \\
\text { students }\end{array}$ & $\begin{array}{c}\text { Cape Coast, } \\
\text { Ghana }\end{array}$ & $\begin{array}{l}\text { Awareness of platforms: Alison (202/467, 43.3\%); Moodle } \\
\text { (132/467, 28.3\%); Google Classroom (125/467, 26.8\%) } \\
\text { Preference for e-Learning: WhatsApp (236/467, 50.5\%) } \\
\text { Google Meeting (85/467, 18.2\%); Zoom (82/267, 17.6\%) } \\
\text { Devices used for e-Learning: smartphones (358/467, } \\
\text { 76.7\%); laptops (40/467, 8.6\%); no device (62/467, 13.3\%) } \\
\text { Device proficiency for e-Learning: smartphones (186/467, } \\
\text { 39.8\%); laptops (161/467, 34.5\%); uncertain (106/467, } \\
22.7 \%)\end{array}$ \\
\hline
\end{tabular}

\begin{tabular}{|c|c|c|c|c|}
\hline $\begin{array}{l}\text { Cassibba et al. } \\
(2021)\end{array}$ & $\begin{array}{c}\text { Mixed } \\
\text { Methods survey }\end{array}$ & $\begin{array}{l}27 \\
\text { educators }\end{array}$ & Sicily, Italy & $\begin{array}{l}\text { Most frequently used: Microsoft teams (100\%); writing } \\
\text { tablets (61\%); mathematical software (e.g. Mathematica; } \\
37 \%)\end{array}$ \\
\hline $\begin{array}{l}\text { Irfan et al. } \\
\text { (2020) }\end{array}$ & $\begin{array}{l}\text { Qualitative } \\
\text { survey }\end{array}$ & $\begin{array}{c}26 \\
\text { educators }\end{array}$ & $\begin{array}{l}\text { Sumatra, Java, } \\
\text { Kaliman-tan, } \\
\text { and } \\
\text { Sulawesi, } \\
\text { Indonesia }\end{array}$ & $\begin{array}{l}\text { Most used platforms: Google Classroom (32\%); Zoom } \\
(24 \%) ; \text { Edmodo (24\%); Skype (8\%); university LMS (8\%) } \\
\text { Challenges reported: animation, object-oriented } \\
\text { programming (Adobe Flash and web design), and video } \\
\text { editing }\end{array}$ \\
\hline
\end{tabular}




\begin{tabular}{|c|c|c|c|c|}
\hline $\begin{array}{l}\text { Lopez et al. } \\
\qquad(2021)\end{array}$ & $\begin{array}{c}\text { Mixed methods } \\
\text { survey }\end{array}$ & $\begin{array}{c}51 \\
\text { educators }\end{array}$ & Texas, U.S. & $\begin{array}{l}\text { Added technologies during the Covid-19 pandemic: video } \\
\text { platforms (e.g. Zoom, 92\%); online quizzes (75\%); } \\
\text { instructional videos (57\%); social media communications } \\
\text { (27\%) Challenges reported: lack of preparation andtraining }\end{array}$ \\
\hline Naidoo (2020) & $\begin{array}{c}\text { Qualitative inter- } \\
\text { pretivist }\end{array}$ & $\begin{array}{l}31 \text { post- } \\
\text { graduate } \\
\text { students }\end{array}$ & $\begin{array}{l}\text { KwaZulu- } \\
\text { Natal, South } \\
\text { Africa }\end{array}$ & $\begin{array}{l}\text { Preferred platform: WhatsApp for immediatefeedback and } \\
\text { easy resource sharing Challenges reported: lack of } \\
\text { training and adjustments to Zoom; uncomfortable with } \\
\text { Moodle }\end{array}$ \\
\hline $\begin{array}{l}\text { Siregar et al. } \\
\quad(2021)\end{array}$ & $\begin{array}{l}\text { Qualitative } \\
\text { descriptive }\end{array}$ & $\begin{array}{c}200 \\
\text { educators }\end{array}$ & $\begin{array}{c}\text { Medan, } \\
\text { Indonesia }\end{array}$ & $\begin{array}{l}\text { Most used: WhatsApp (92/200, 46\%) Generational } \\
\text { differences: Millennials (born 1981-1994) most frequently } \\
\text { combined group chat platforms and LMS; Baby Boomers } \\
\text { (born 1946-1964) mostly used group chat platforms }\end{array}$ \\
\hline $\begin{array}{c}\text { Sulistyani etal. } \\
(2021)\end{array}$ & $\begin{array}{l}\text { Qualitative } \\
\text { descriptive }\end{array}$ & $\begin{array}{c}14 \\
\text { educators }\end{array}$ & $\begin{array}{l}\text { Yogyakarta, } \\
\text { Indonesia }\end{array}$ & $\begin{array}{l}\text { Most used: social media (WhatsApp or LINE, 11/14, } \\
78.6 \% \text { ); asynchronous videos }(11 / 14,78.6 \%) \text {; LMS } \\
\text { (Moodle or Google Classroom, 10/14, 71.4\%); text files } \\
\text { (PDF, Word, PowerPoint,9/14, 64.3\%); synchronous videos } \\
\text { (Zoom, MS Teams, or Skype, 6/14, 42.9\%); evaluation } \\
\text { software (Quizizz, 1/14, 7.1\%) }\end{array}$ \\
\hline
\end{tabular}

RQ2: What were the changes in educators' practices of teaching postsecondary mathematics during the Covid19 pandemic?

Changes in educators' practices were reported in only three (33.3\%) studies (see Table 3). These studies comprised one (33.3\%) qualitative study and two (66.7\%) mixed methods studies from different geographical locations. Samples were all educators and the sample sizes ranged from 14 to 51 . None of the educators in Cassibba et al.'s (2021) study in Italy had prior experiences with lecturing online before the Covid19 pandemic. Among educators from Texas in Lopez et al.'s (2021) study, 23\% were certified for e-Learning, 6\% had received some trainingon e-Learning, and 29\% had prior experiences teaching online or blended courses. Sulistyani et al. (2021) did not explicitly report on the prior experiences of their participants in teaching with eLearning.

The findings of the three studies under this subresearch question were varied. A majority of educators (78.6\%) in Sulistyani et al.'s (2021) study in Indonesia stated that they were able to successfully achieve educational goals without modifying their teaching practices or strategies in e-Learning, and only $14.3 \%$ reported modifications in teaching practices or strategies. These results are somewhat contrary to the changes reported in Cassibba et al.'s (2021) and Lopez et al.'s (2021) studies. Educators in Cassibba et al.'s study in Italy stated that they had to increase their preparation for e-Learning, used less gestures, and were able to do more with their lessons given the same amount of time because they sent notes prior to each lesson; however, the faster pace was also attributed to the decrease in student interactions. A majority (64\%) of Cassibba et al.'s participants, independent of their number of students, had difficulty perceiving whether their students kept up with their lessons. Those who were able to perceive their students' ability to keep up with the lessons mostly had to ask students directly $(30 \%)$. Notably, practices in terms of language and representations used were mostly retained (Cassibba et al., 2021). In Lopez etal.'s (2021) study in Texas, the changes reported were significant increases in time spent on teaching tasks and on technology usage.

Table 3: Changes in Educators' Practices

\begin{tabular}{|c|c|c|c|c|}
\hline Author (Year) & Method & Sample & Location & Results \\
\hline $\begin{array}{c}\text { Cassibba et al. } \\
\qquad(2021)\end{array}$ & $\begin{array}{l}\text { Mixed } \\
\text { methods } \\
\text { survey }\end{array}$ & $\begin{array}{c}27 \\
\text { educators }\end{array}$ & Sicily, Italy & $\begin{array}{l}\text { Changes with e-Learning: increased preparation; less } \\
\text { gestures; pre-sent notes; lack of student interaction; } \\
\text { unable to perceive whether students kept up with lessons } \\
\text { Retained: use of natural language, mathematicallanguage } \\
\text { and iconic representations }\end{array}$ \\
\hline $\begin{array}{l}\text { Lopez et al. } \\
\quad(2021)\end{array}$ & $\begin{array}{c}\text { Mixed } \\
\text { methods } \\
\text { survey }\end{array}$ & $\begin{array}{c}51 \\
\text { educators }\end{array}$ & Texas, U.S. & $\begin{array}{l}\text { Hours increased: educators with one or two courses from } \\
11.4 \text { to } 17.3 \text { hours per week ( } 52 \% \text { increase); educators } \\
\text { with three or more courses from } 28.5 \text { to } 38.9 \text { hours per } \\
\text { week ( } 36 \% \text { increase) Technology usage: youngest group } \\
\text { (aged } 24 \text { to } 39 \text { years) from } 2.8 \text { to } 5.5 \text { ( } 96 \% \text { increase) } \\
\text { middle group (aged } 40 \text { to } 54 \text { years) from } 3 \text { to } 5.6 \text { ( } 87 \% \\
\text { increase); oldest group (aged } 55 \text { years and above) from } 3 \\
\text { to } 5 \text { ( } 67 \% \text { increase), all significantat ( } p<0.0001 \text { ) }\end{array}$ \\
\hline
\end{tabular}




$\begin{array}{cccc}\begin{array}{c}\text { Sulistyani et al. } \\ (2021)\end{array} & \begin{array}{l}\text { Qualitative } \\ \text { descriptive }\end{array} & \begin{array}{c}14 \\ \text { educators }\end{array} & \begin{array}{c}\text { Yogyakarta, } \\ \text { Indonesia }\end{array}\end{array}$

$11 / 14 \quad(78.6 \%)$ of educators indicated successful achievement of educational goals without modification upon shifting to e-Learning; $2 / 14(14.3 \%)$ of educators indicated success withunspecified modifications
RQ3: How did postsecondary educators perceive mathematics e-Learning during the Covid-19pandemic?

Four out of the nine studies (44.4\%) in this systematic review reported on educators' perceptions regrading mathematics e-Learning (see Table 4). These studies included two (50\%) qualitative and two (50\%) mixed methods studies. Two studies (50\%) took place in Indonesia, one (25\%) in Italy, and one (25\%) in Texas, United States. Sample sizes varied from 14 to 51.

Educators' perceptions regarding mathematics e-Learning mostly involved challenges invarious aspects of e-Learning with a few advantages. Only Irfan et al. (2020) did not report any perceived advantages of mathematics e-Learning. The main advantages identified were improvedstudent involvement (Cassibba et al., 2021; Sulistyani et al., 2021), improved lesson planning (Cassibba et al., 2021), and improved teaching style as well as comfort with technologies (Lopezet al., 2021). More challenges were identified within the studies, as listed in Table 4. Notably, Lopez et al. (2021) reported a significant increase in educators' willingness to teach online.

Table 4: Educators' Perceptions of Mathematics e-Learning

\begin{tabular}{|c|c|c|c|c|}
\hline Author (Year) & Method & Sample & Location & Results \\
\hline $\begin{array}{c}\text { Cassibba etal. } \\
(2021)\end{array}$ & $\begin{array}{l}\text { Mixed } \\
\text { methods } \\
\text { survey }\end{array}$ & $\begin{array}{c}27 \\
\text { educators }\end{array}$ & Sicily, Italy & $\begin{array}{l}\text { Advantages of e-Learning: improved student } \\
\text { involvement because of increased student } \\
\text { responsibility; improved lesson planning Challenges: } \\
\text { loss of human exchange (43\%); loss of student } \\
\text { interactions }(27 \%)\end{array}$ \\
\hline $\begin{array}{c}\text { Irfan et al. } \\
(2020)\end{array}$ & $\begin{array}{c}\text { Qualitative } \\
\text { survey }\end{array}$ & $\begin{array}{c}26 \\
\text { educators }\end{array}$ & $\begin{array}{l}\text { Sumatra, Java, } \\
\text { Kaliman-tan, } \\
\text { and Sulawesi, } \\
\text { Indonesia }\end{array}$ & $\begin{array}{l}\text { Challenges: limited delivery methods becauseof lack of } \\
\text { special software for mathematics; difficulty monitoring } \\
\text { students' struggles }\end{array}$ \\
\hline $\begin{array}{l}\text { Lopez et al. } \\
\qquad(2021)\end{array}$ & $\begin{array}{l}\text { Mixed } \\
\text { methods } \\
\text { survey }\end{array}$ & $\begin{array}{c}51 \\
\text { educators }\end{array}$ & Texas, U.S. & $\begin{array}{l}\text { Advantages: increased comfort level with technologies } \\
\text { (69\%); improved teaching style (55\%) Top Challenges } \\
\text { (out of } 102 \text { points): testing (83); encouraging student } \\
\text { interactions with each other (81) Medium Level } \\
\text { Challenges: professor-student interactions (66); } \\
\text { absenteeism (63); personal teaching styles (61); } \\
\text { student connectivity (58); work-life balance (53); time } \\
\text { management (48); remote office hours (44) Low Level } \\
\text { Challenges: whiteboard use (39); homework (38); } \\
\text { educator connectivity (32); LMS (16) Willingness to } \\
\text { teach online: significant increase from } 5 \text { (10\%) to 19 } \\
\text { (37\%) educators ( } p<0.0005)\end{array}$ \\
\hline $\begin{array}{c}\text { Sulistyani et al. } \\
\text { (2021) }\end{array}$ & $\begin{array}{l}\text { Qualitative } \\
\text { descriptive }\end{array}$ & $\begin{array}{c}14 \\
\text { educators }\end{array}$ & $\begin{array}{c}\text { Yogyakarta, } \\
\text { Indonesia }\end{array}$ & $\begin{array}{l}\text { Advantages: student involvement in learning (92.9\%); } \\
\text { student involvement in discussions }(78.6 \%) \text { Future } \\
\text { Improvements for e-Learning: increased preparation in } \\
\text { terms of content and time }(71.4 \%) \text {; more varied } \\
\text { technology use }(50 \%) \text {; more innovative and } \\
\text { communicative delivery methods }(50 \%) \text {; outcome- } \\
\text { based learning adjustments }(28.6 \%) \text {; continued focus } \\
\text { on deepening student experience }(7.1 \%)\end{array}$ \\
\hline
\end{tabular}

RQ4: How did postsecondary students perceive mathematics e-Learning during the Covid-19pandemic?

Four out of the nine studies (44.4\%) in this systematic review addressed this sub-researchquestion regarding students' perceptions of mathematics eLearning (see Table 5). Three of the studies (75\%) were conducted in Africa, while one study (25\%) was conducted in Western United States. Two quantitative studies (50\%) involved undergraduate students, and two qualitative studies (50\%) involved post-graduate students. Sample sizes varied from 20 to 467.

Qualitative findings highlighted both advantages and challenges with mathematics eLearning. The main advantages perceived by postgraduate students included the ability to revisitlessons, having virtual communities of practice, development of technological skills, improvements in technical problem solving skills, and enhanced communication and 
research skills (Naidoo, 2020; Nsengimana et al., 2021). The main challenges perceived by post-graduate students included increased costs, lack of internet access, lack of practical and hands-on activities, unclear instructions, limited collaboration, lack of ICT knowledge, insufficient feedback, and distractions and responsibilities at home (Naidoo, 2020; Nsengimana et al., 2021).

Quantitative data for this sub-research question involved the challenges with mathematics e-Learning. The main challenges perceived by undergraduate students were mostly similar to those perceived by postgraduate students with the addition of feeling unprepared for e-Learning, increased anxiety about mathematics e-Learning, and the negative effects of
Covid-19 on their mathematics learning abilities (Agormedah et al., 2020; Ludwig, 2021). An interesting, albeit non-significant finding by Ludwig (2021) was that students with high anxiety, strong negative perceptions about the effect of Covid-19 on their mathematics learning abilities, and neutral perceptions of e-Learning had the lowest midterm scores averaging at 80 points, which was one standard deviation below average. No advantages of mathematics e-Learning were reported in the quantitative studies; however, this may be due to the rigid nature of the instruments used rather than the lack of advantages per se. In Agormedah et al.'s (2020) study in Ghana, a majority (56.7\%) of students considered e-Learning to be necessary.

Table 5: Students' Perceptions of Mathematics E-Learning

\begin{tabular}{|c|c|c|c|c|}
\hline Author (Year) & Method & Sample & Location & Results \\
\hline $\begin{array}{c}\text { Agormedah et al. } \\
(2020)\end{array}$ & $\begin{array}{c}\text { Quantitative } \\
\text { survey }\end{array}$ & $\begin{array}{c}467 \\
\text { under- } \\
\text { graduate } \\
\text { students }\end{array}$ & $\begin{array}{l}\text { Cape } \\
\text { Coast, } \\
\text { Ghana }\end{array}$ & $\begin{array}{l}\text { Challenges: access to continuous internet connection (55.5\% } \\
\text { had no access, } 29.8 \% \text { were unsure); finances for internet data } \\
\text { (67.9\% could not afford enough data, } 23,1 \% \text { were unsure); } \\
\text { unfamiliarity with e- Learning (86.7\% were unfamiliar, } 91.9 \% \text { used } \\
\text { e- Learning for the first time); preparation for e- Learning (47.5\% } \\
\text { felt unprepared, } 19.9 \% \text { were unsure) Perception of e-Learning: } \\
56.7 \% \text { considered it necessary, } 43.3 \% \text { did not consider it } \\
\text { necessary }\end{array}$ \\
\hline $\begin{array}{l}\text { Ludwig } \\
\text { (2021) }\end{array}$ & $\begin{array}{c}\text { Quantitative } \\
\text { survey }\end{array}$ & $\begin{array}{c}120 \\
\text { under- } \\
\text { graduate } \\
\text { students }\end{array}$ & $\begin{array}{l}\text { Western } \\
\text { United } \\
\text { States }\end{array}$ & $\begin{array}{l}\text { Challenges: anxiety about mathematics e-Learning (mean } \\
6.3 / 10) ; \text { Covid-19 effects on mathematics learning ability (mean } \\
4 / 10 \text { ) Perception of e-Learning: neutral (mean 4.7/10) Non- } \\
\text { significant Correlations: students with high anxiety levels scored } \\
6.2 \text { points ( } 0.4 \text { standard deviations) below average in midterm } \\
\text { exams (not significant); students with high anxiety, strong } \\
\text { negative perceptions about Covid- } 19 \text { effects on mathematics } \\
\text { learning ability, and neutral perception of e-Learning scored } \\
\text { lowest in midterm exams ( } 80 \text { points, } 1 \text { standard deviation below } \\
\text { average, not significant) }\end{array}$ \\
\hline
\end{tabular}

Naidoo

(2020)

Qualitative
inter-pretivist
graduate students

Natal,

South

Africa

Advantages: ability to revisit lessons with asynchronous ecordings and resources; creation of virtual communities of practice for collaboration and online social support Challenges: device, data, and resource costs; family responsibilities and distractions at home

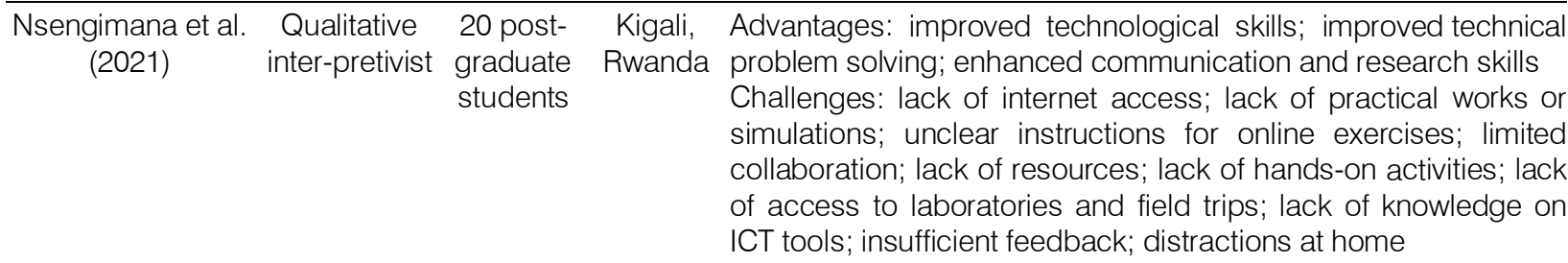

\section{Discussion}

The findings of this systematic review involved the transitional experiences of postsecondary educators and students regarding mathematics e-Learning during the Covid-19 pandemic in six different countries. The narrow focus on mathematics and the period of the Covid-19 pandemic allowed for a specialized overview of this field during this challenging period, hence the limited number of studies included in the review. The studies were further clustered around certain geographic locations including Indonesia, the United States, and African countries. Nonetheless, the findings from these studies provided a general overview of the technologies used, changes in practices, and perceptions of postsecondary educators and students regarding mathematics e-Learning. 
The findings regarding technologies used for eLearning during the Covid-19 pandemic highlighted the variability in available technologies for communications and LMS; however, the most prevalent were Google classroom, Moodle, and WhatsApp (Agormedah et al., 2020; Irfan et al., 2020; Naidoo, 2020; Siregar et al., 2021; Sulistyani et al., 2021). It appears that few educators utilized more specialized technologies such as evaluation software or mathematical software. Some educators in Irfan et al.'s (2020) study stated that they wished there were available systems for attendance and assessment, which reflected a lack of awareness regarding such software. Such findings supported the idea that even digital natives may be unprepared for eLearning as they may only be familiar with technologies for personal use rather than for e-Learning (Nsengimana et al., 2021). These findings also supported Ahn and Edwin's (2018) idea that specialized software use remains scarce due to difficulties in setup and high costs. As institutions and educators continue to adjust towards e-Learning, it may be helpful to develop more user-friendly and universal software that they could use, and to raise awareness regardingthese technologies.

In terms of the changes in educators' practices for e-Learning, the main issue appeared to be the increased preparation required for teaching tasks (Cassibba et al., 2021; Lopez et al., 2021). Only Cassibba et al. (2021) reported the use of less gestures, which was purported to be a vital part of mathematics education. The increase in use of technologies reported by Lopez et al. (2021) was unsurprising as it is the main principle of e-Learning (Ayu, 2020). No other major changes in practice and strategies were reported. The finding that a majority of educators in Sulistyani et al.'s (2021) study were able to successfully achieve their goals without major changes shows some promise for the use of e-Learning in mathematics. Cassibba et al.'s (2021) participants likewise indicated that they retained the use of natural language, mathematical language, and iconic representations, which is important for the subject of mathematics (Ahn \& Edwin, 2018). Although the minimal changes found in this review is promising, educators shouldalso find ways to maximize the benefits of technologies and apply positive changes to their practices and strategies.

Postsecondary educators' perceptions regarding mathematics e-Learning were somewhat mixed, with more challenges reported than benefits. The loss of student interactions and involvement in lessons and discussions appeared to be a major challenge for educators (Cassibba et al., 2021; Irfan et al., 2020; Sulistyani et al., 2021). This challenge supported Neuwirth et al.'s (2020) idea that teaching on a screen with minimal visual feedback can serve as a barrier for student engagement. This challenge also limits the opportunities for student collaboration, which was cited as an important factor for mathematics education
(Naidoo, 2020; Nsengimana et al., 2021). Alternatively, the main advantage of e-Learning appeared to be the improvements in student involvement because of their increased responsibilities (Cassibba et al., 2021; Sulistyani et al., 2021). The increase in student responsibilities, however, may be counterproductive for students who are experiencing Covid despair (Ludwig, 2021). As educators in Lopez et al.'s (2021) study indicated work-life balance as a medium-level challenge for them, educators shouldalso consider the needs of their students during this difficult period.

Relatively more challenges with mathematics e-Learning were reported by students, while only two studies reported on benefits. The advantage of increased technological, problem solving, communication, and research skills (Nsengimana et al., 2021) support the idea that students can adjust and progress from digital immigrants to digital natives (Naidoo, 2020).

Interestingly, a key advantage identified in Naidoo's (2020) study was the creation of virtual communities, which could be a solution to the educators' perceived challenge of loss of student interactions and collaboration (Cassibba et al., 2021; Lopez et al., 2021; Sulistyani et al., 2021). The challenges identified by the postsecondary students supported existing literature indicating lack of readiness for e-Learning (Sakhapov \& Absalyamova, 2018), possible distractions at home, and other psychosocial factors (Neuwirth et al. 2020). The challenge of family responsibilities may be especially pronounced for postsecondary students who have children (Naidoo, 2020). Students should thus be given more time to adjust and training in preparation fore-Learning. Overall, mathematics e-Learning may be necessary for the time being and may have benefits, but the multiple challenges identified in this review indicate a need to further develop the field.

\section{Limitations}

A major limitation for this systematic review is the small number of studies that met the criteria. Although this limitation could not be controlled due to the narrow focus of the review, it limits the opportunities for comparison and synthesis. Additional research is needed to provide a more solid evidence regarding the transitional experiences of postsecondary educators and students for mathematics e-Learning during the Covid-19 pandemic. Notable geographical limitations were also found in this systematic review, with most studies clustering in Africa and Indonesia. Similar studies in other nations, especially in South America and Australia would be particularly helpful in providing a more diverse and global view of the field. More quantitative evidence with larger sample sizes would also be beneficial to obtain a more holistic overview of 
the transitional experiences of educators and students regarding postsecondary mathematics e-Learning during the Covid-19 pandemic.

Availability of Data and Materials

The dataset for this article were derived from peer-reviewed scientific publications, which are listed as references.

Competing Interests

The author declares that they have no competing interests

Funding

This review received no external funding

Vil. List of AbBreviations

4IR Fourth Industrial Revolution

Covid-19 Coronavirus 2019

ICT Information and Communications Technologies

LMS Learning Management Systems

PRISMA Preferred Reporting Items for Systematic Reviews and Meta-Analyses

UNESCO United Nations Educational, Scientific and Cultural Organization

\section{References Références Referencias}

1. Agormedah, E. K., Henaku, E. A., Ayite, D. M. K., \& Ansah, E. A. (2020). Online learning in higher education during COVID-19 pandemic: A case of Ghana. Journal of Educational Technology and Online Learning, 3(3), 183-210. https://doi.org/10.31 681/jetol.726441

2. Ahn, J. Y., \& Edwin, A. (2018). An e-Learning model for teaching mathematics on an open source learning platform. International review of research in open and distributed learning, 19(5). https://www. erudit.org/en/journals/irrodl/1900-v1-n1-irrodl04235/ 1055557ar/abstract/

3. Attiah, K. (2020, September 22). Africa has defied the covid-19 nightmare scenarios. We shouldn't be surprised. The Washington Post. https://www.wash ingtonpost.com/

4. Ayu, M. (2020). Online learning: Leading e-Learning at higher education. The Journal of English Literacy Education: The Teaching and Learning of English as a Foreign Language, 7(1), 47-54. https://www. academia.edu/download/63817004/11515-30041-1PB20200703-5942-181j0kl.pdf

5. Cassibba, R., Ferrarello, D., Mammana, M. F., Musso, P., Pennisi, M., \& Taranto, E. (2021). Teaching mathematics at distance: A challenge for universities. EducationSciences, 11(1), 1. https://dx. doi.org/10.3390/educsci11010001
6. Gough, D., Oliver, S., \& Thomas, J. (Eds.). (2017). An introduction to systematic reviews. Sage.

7. Irfan, M., Kusumaningrum, B., Yulia, Y., Widodo, S. A. (2020). Challenges during the pandemic: Use of e-Learning in mathematics learning in higher education. Infinity Journal of Mathematics Education, 9(2), 147-158. https://doi.org/10.22460/infinity.v9i2. p147-158

8. Lopez, S. R., Bruun, G. R., Mader, M. J., \& Reardon, R. F. (2021). The Pandemic Pivot: The Impact of COVID-19 on Mathematics and Statistics PostSecondary Educators. International Journal for Cross-Disciplinary Subjects in Education, 12(1), 4369-4378. https://doi.org/10.20533/ijcdse.2042.63 64.2021 .0535

9. Ludwig, J. (2021). Poor performance in undergraduate math: Can we blame it on COVID-19 despair?. International Journal of Innovation in Science and Mathematics, 9(3), 31-40. http://ijism. org/administrator/components/com_jresearch/files/p ublications/IJISM_934_FINAL.pdf

10. Marinoni, G., Van't Länd, H., \& Jensen, T. (2020). The impact of Covid-19 on higher education around the world. IAU Global Survey Report. https://www. iau-aiu.net/IMG/pdf/iau_covid19_and_he_survey_ report final may 2020.pdf

11. Naidoo, J. (2020). Postgraduate mathematics education students' experiences of using digital platforms for learning within the COVID-19 pandemic era. Pythagoras, 41(1), 568. https://eric. ed.gov/?id=EJ1286885

12. Neuwirth, L. S., Jović, S., \& Mukherji, B. R. (2020). Reimagining higher education during and postCOVID-19: Challenges and opportunities. Journal of Adult and Continuing Education, 1-16. http://dx.doi. org/10.1177/1477971420947738

13. Nsengimana, T., Bazimaziki, G., Nyirahabimana, A., Mushimiyimana, J. B., Mutarutinya, V., Mugabo, L. R., \& Nsengimana, V. (2021). Online Learning during COVID-19 pandemic in Rwanda: Experience of postgraduate students on language of instruction, mathematics and science education. Contemporary Mathematics and Science Education, 2(1), 1-7. https://www.conmaths.com/article/onlineLearning-during-covid-19-pandemic-in-rwanda-expe rience-of-postgraduate-students-on-language-10788

14. Olivia, S., Gibson, J., \& Nasrudin, R. A. (2020). Indonesia in the Time of Covid-19. Bulletin of Indonesian Economic Studies, 56(2), 143-174. https://doi.org/10.1080/00074918.2020.1798581

15. Page, M. J., McKenzie, J. E., Bossuyt, P. M., Boutron, I., Hoffmann, T. C., Mulrow, C. D., ... \& Moher, D. (2021). The PRISMA 2020 statement: an updated guideline for reporting systematic reviews. Bmj, 372. https://doi.org/10.1136/bmj.n71 
16. Saglietto, A., D'Ascenzo, F., Zoccai, G. B., \& De Ferrari, G. M. (2020). COVID-19 in Europe: the Italian lesson. The Lancet, 395(10230), 1110-1111. https://doi.org/10.1016/

17. Sakhapov, R., \& Absalyamova, S. (2018). Fourth industrial revolution and the paradigm change in engineering education. In MATEC Web of Conferences (Vol. 245, p. 12003). EDP Sciences.

18. Siregar, G. M. A., Hidayat, Sukmawarti, \& Siagian, M. D. (2021). Evaluation of online learning for mathematics education students. Journal of Physics: Conference Series, 1882(1), 1-8. https://doi .org/10.1088/1742-6596/1882/1/012064

19. Stiegler, N., \& Bouchard, J. P. (2020). South Africa: Challenges and successes of the COVID-19 lockdown. Annales medico-psychologiques, 178(7), 695-698. https://doi.org/10.1016/j.amp.2020.05.006

20. Sulistyani, N., Utomo, B., \& Kristanto, Y. D. (2021). Emergency remote teaching experiences of mathematics education lectures to address COVID19 pandemic. Journal of Physics: Conference Series, 1806(1). https://iopscience.iop.org/article/10. 1088/1742- 6596/1806/1/012088/meta

21. Tamrat, W. \& Teferra, D. (2020, April 9). COVID-19 poses a serious threat to higher education. University World News. https://www.universityworld news.com/ 